\title{
Prototype Monitoring Temperature and Humidity Sensor Room Server-Based Internet of Things (IOT)
}

\author{
Mohammad Ridwan ${ }^{1}$, Djamaludin ${ }^{2}$, Muhammad Roqib ${ }^{3}$ \\ \{mridwan@unis.ac.id ${ }^{1}$, djamaludin@unis.ac.id ${ }^{2}$, tofikguntoro@gmail.com ${ }^{3}$ \}
}

Informatics Engineering Study Program, Islamic University of Sheikh Yusuf Tangerang, St. Maulana Yusuf Tangerang 15118, Indonesia $^{1,2,3}$

\begin{abstract}
Computer servers are very important to provide resources to be used for computer users in a network. Temperature and humidity in the server room are things that must be addressed to remain in normal, so as to minimize damage to server computer hardware, a system consisting of secure devices and hard devices using a microcontroller consisting of NodeMCU, DHT 11 temperature sensor, LCD I2C, temperature \& humidity data will be displayed in real-time on the website and also get notifications via e-mail and telegram if the temperature and humidity exceed the normal limit .
\end{abstract}

Keywords: Server, Temperature, Humidity, Microcontroller.

\section{Introduction}

The server is the center for storing data, in which there is a lot of data and information such as databases or other data that can be accessed through theinternet network. In this case, the server computer mustbe considered and maintained the health of the hardware that is in it, becausethis device continues to be used for a long time and often performs a process that is so heavy that it requires futures maintenance, one of the thing that become a parameter that affects the health of a hardware device on a server computer that is temperature and humidity. General temperature and humidity standards for maintaining room temperature According to the American Society of Heating Refrigerating and Air-Conditioning Engineers (ASHRAE) in the Thermal Guidelines (2015), to recommend server roomtemperatures should not be less than $15^{\circ} \mathrm{C}\left(59^{\circ} \mathrm{F}\right)$ or more than $32^{\circ} \mathrm{C}\left(89.6^{\circ} \mathrm{F}\right)$. so the server room temperature is recommended to be at a temperature between $18^{\circ}-27^{\circ} \mathrm{C}\left(64.4^{\circ}-80.6^{\circ} \mathrm{F}\right)$ and also humidity ranging from $45 \%-55 \%$ this can vary under certain conditions. To be able to monitor temperature and humidity on a server that is operating, therefore a system that will be able to provide information directly or often we call it in real-time if there is an instability of temperature and humidity on the server when there is a process that is not going well the systemit will send notifications via the internet. Admin can access any where the temperature and humidity monitoring sy stemby utilizing the Internet of Things (IoT).

\section{Research Me thods}

\subsection{Method of Collecting Data}

Observation Method, Knowing the temperature and humidity in the server room, and overcome by building a system to be able to increase the temperature and comfort and control the computer server if abnormal temperatures occur with the remote server, Target is observing in the Server Room of the Task Unit of the Management Information System of Is lamic University of Sheikh Yusuf.

Interview Method, conducted through face to face and question and ans wer directly with interested parties . Library Study Method, conducted through the collection of literature, journals, articles, and readings that are related to the title of the study as a reference in the preparation of this report.

\subsection{SystemPlanning}

The process of building this systemis divided into two parts, namely hardware design and software design user interface.

A. Tool Design

a. DHT11 Sensor Circuit to NodeMCU 
The VCC pin from DHT11 is connected to the 5v NodeMCU Base Board, the DHT11 Signal pin is connected to pin D5 on the NodeMCU Base Board, and the DHT11 Ground Pin is connected to the GND PIN on the Base Board.

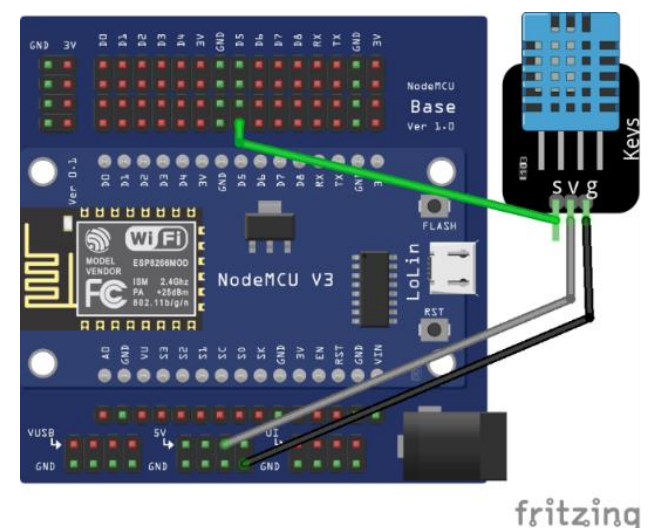

Figure 1. DHT11 Sens or Circuit

b. I2C LCD circuit to NodeMCU

The LCD Ground Pin is connected to the GND Base Board NodeMCU Pin, the VCC pin is connected to the $5 \mathrm{v}$ power on the NodeMCU Base Board, the SDA and SCLpins are connected to the D1 and D2 pins on the NodeMCU board.

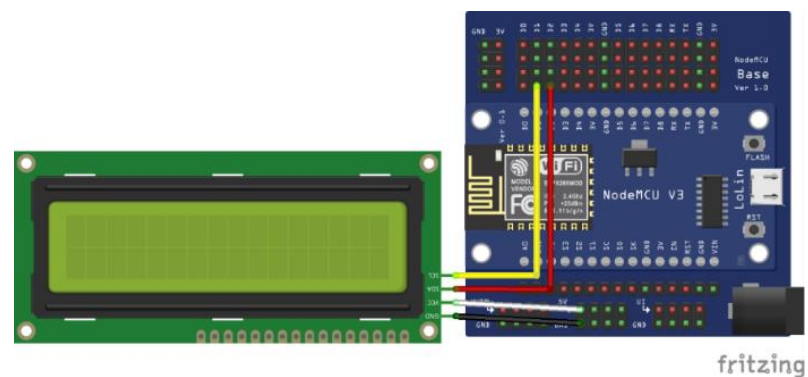

Figure 2. LCD Sens or Circuit

c. NodeMCU circuit to the Base Board Base Plate

NodeMCU only plugs into the Base Board with the available pins then the Base Board requires a DC adapter and is connected to the power source.

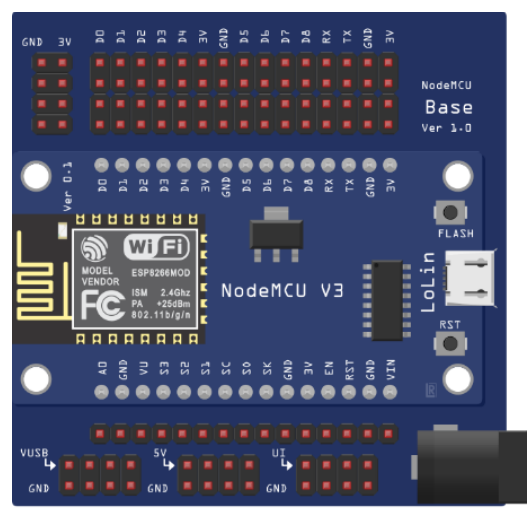

$$
\text { fritzing }
$$

Figure 3. NodeMCU Baseboard Circuit

B. Software Design

To be able to interact via the website, user interface design is needed to monitor temperature and humidity control in the SIM UNIS UPT server room, the menu of this website is divided into 5 sections, namely home, 
charts, computer control, data report log tables and login pages, and following the Architectural Design, Flowchart and Class Diagram of this system.

a. Architecture Series

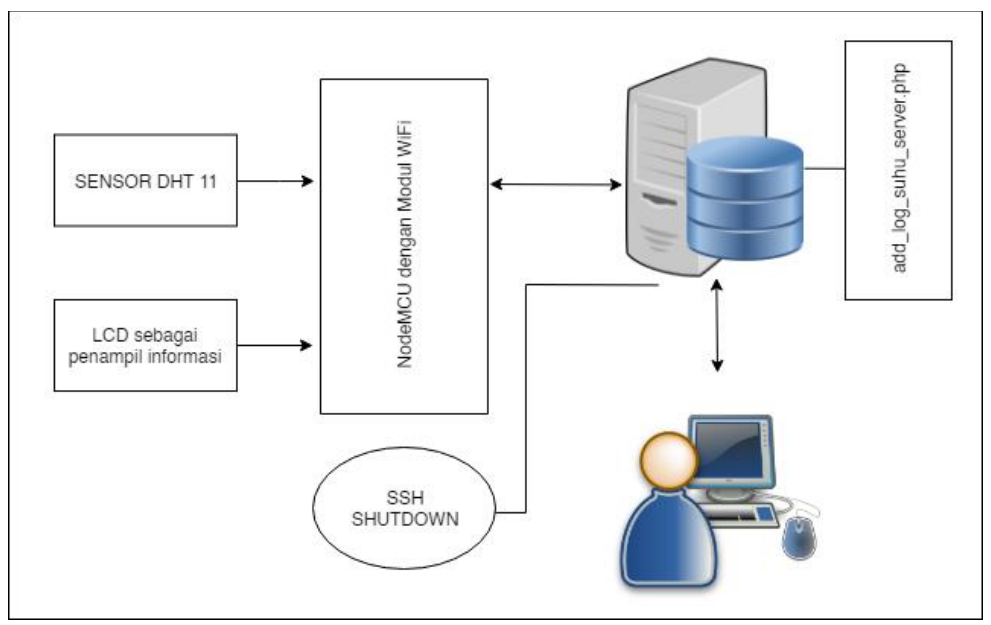

b. Flowchart

Figure 4. Architecture Series

Flowchart aims to show the workflow system of the system that has been made, the following explanation.

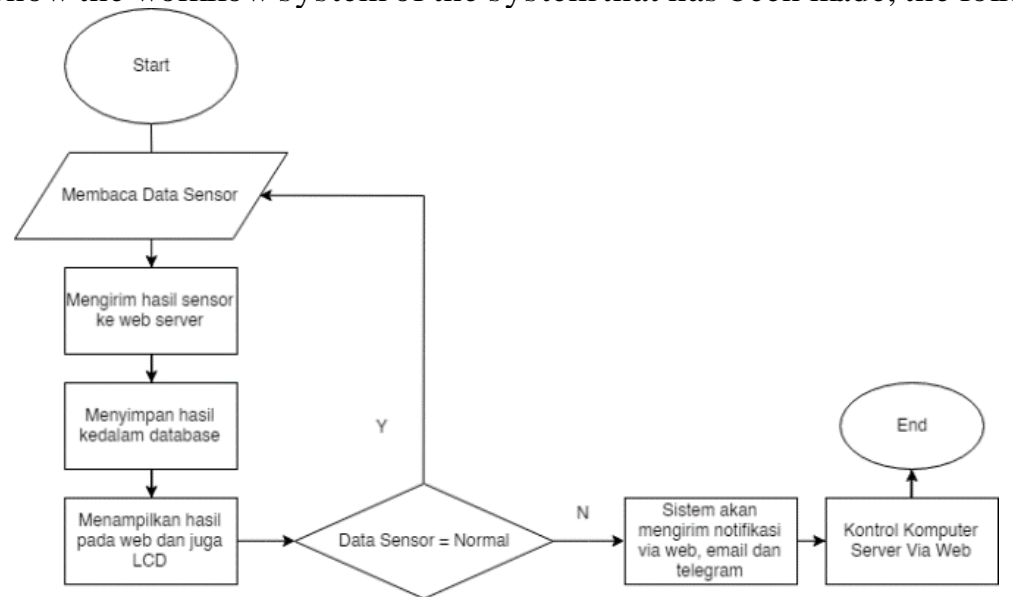

Figure 5. Flowchart

c. Class Diagram

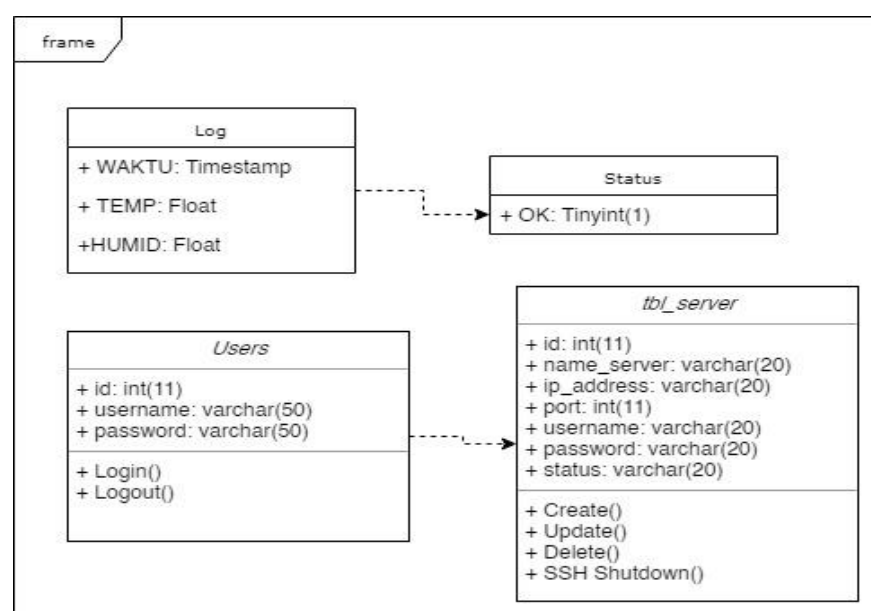

Figure 6. Class Diagram 


\section{Result and Discussion Research}

\subsection{Implementation System}

will discuss the testing tools along with the appearance of the website interface based on a system that has been planned and made that aims to find out how this tool works well and know the success of the design of the tool in its performance in accordance with the specifications specified. The testing of this system goes through several stages, namely testing each part of the system to the overall system testing so that a temperature and humidity monitoring system is formed in the UPT SIM UNIS server room.

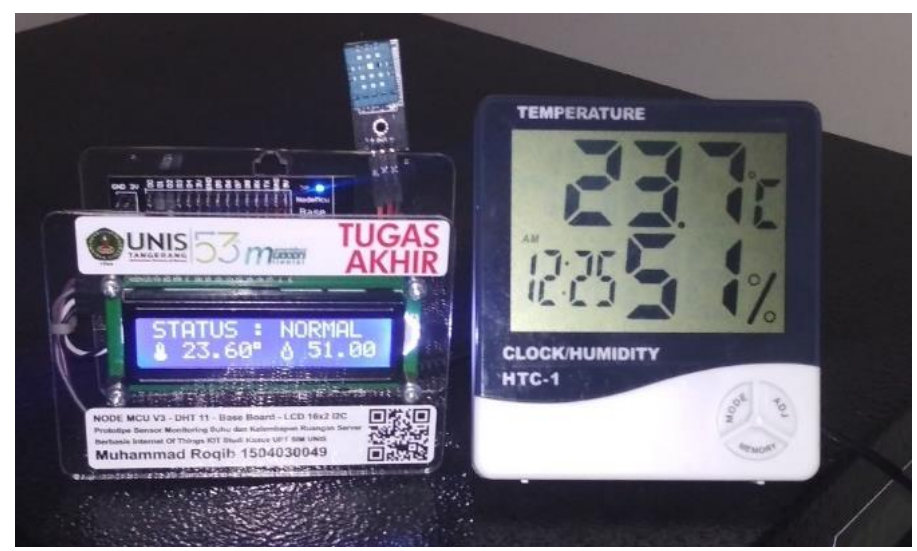

Figure 7. Comparis on of Tools in a Server Room

3.2. Testing the Accuracy of Temperature Sensors and Humidity DHT11

Sensortesting is done by comparing the DHT11 sensor with a Digital Thermometer, temperature and humidity samples are taken once every minute, and 10 samples are generated in 10 minutes in the UPT UNIS server room and outside the server room.

Table 1. Comparison Outside the Server Room

\begin{tabular}{|c|c|c|c|}
\hline \multicolumn{4}{|c|}{ Outside the Server Room } \\
\hline \multicolumn{2}{|c|}{ IoT Tool } & \multicolumn{2}{|c|}{ Digital Thermometer } \\
\hline Temperature & Humidity & Temperature & Humidity \\
\hline $28,6{ }^{\circ} \mathrm{C}$ & $51 \%$ & $28,0{ }^{\circ} \mathrm{C}$ & $55 \%$ \\
\hline $28,6{ }^{\circ} \mathrm{C}$ & $51 \%$ & $28,0{ }^{\circ} \mathrm{C}$ & $54 \%$ \\
\hline $28,6{ }^{\circ} \mathrm{C}$ & $51 \%$ & $28,0{ }^{\circ} \mathrm{C}$ & $53 \%$ \\
\hline $28,6{ }^{\circ} \mathrm{C}$ & $50 \%$ & $28,0{ }^{\circ} \mathrm{C}$ & $53 \%$ \\
\hline $28,6{ }^{\circ} \mathrm{C}$ & $50 \%$ & $27,9{ }^{\circ} \mathrm{C}$ & $53 \%$ \\
\hline $28,6{ }^{\circ} \mathrm{C}$ & $50 \%$ & $27,9{ }^{\circ} \mathrm{C}$ & $52 \%$ \\
\hline $28,6{ }^{\circ} \mathrm{C}$ & $51 \%$ & $27,9{ }^{\circ} \mathrm{C}$ & $52 \%$ \\
\hline $28,7{ }^{\circ} \mathrm{C}$ & $50 \%$ & $27,8^{\circ} \mathrm{C}$ & $52 \%$ \\
\hline $28,7{ }^{\circ} \mathrm{C}$ & $50 \%$ & $27,7{ }^{\circ} \mathrm{C}$ & $52 \%$ \\
\hline $28,7{ }^{\circ} \mathrm{C}$ & $50 \%$ & $27,7{ }^{\circ} \mathrm{C}$ & $52 \%$ \\
\hline
\end{tabular}

Table 2. Comparison Inside the Server Room

\begin{tabular}{|c|c|c|c|}
\hline \multicolumn{4}{|c|}{ Inside the Server Room } \\
\hline \multicolumn{3}{|c|}{ Iot Tool } & \multicolumn{2}{c|}{ Digital Thermometer } \\
\hline Temperature & Humidity & Suhu & Humidity \\
\hline $24,3{ }^{\circ} \mathrm{C}$ & $51 \%$ & $25^{\circ} \mathrm{C}$ & $49 \%$ \\
\hline
\end{tabular}




\begin{tabular}{|c|c|c|c|}
$23,9{ }^{\circ} \mathrm{C}$ & $53 \%$ & $24,9{ }^{\circ} \mathrm{C}$ & $49 \%$ \\
\hline $24,2{ }^{\circ} \mathrm{C}$ & $55 \%$ & $24,7{ }^{\circ} \mathrm{C}$ & $50 \%$ \\
\hline $24,5{ }^{\circ} \mathrm{C}$ & $56 \%$ & $24,6{ }^{\circ} \mathrm{C}$ & $50 \%$ \\
\hline $24,8^{\circ} \mathrm{C}$ & $54 \%$ & $24,5{ }^{\circ} \mathrm{C}$ & $50 \%$ \\
\hline $24,3{ }^{\circ} \mathrm{C}$ & $53 \%$ & $24,5{ }^{\circ} \mathrm{C}$ & $50 \%$ \\
\hline $24{ }^{\circ} \mathrm{C}$ & $53 \%$ & $24,3{ }^{\circ} \mathrm{C}$ & $50 \%$ \\
\hline $23,7{ }^{\circ} \mathrm{C}$ & $52 \%$ & $24,2{ }^{\circ} \mathrm{C}$ & $50 \%$ \\
\hline $23,6^{\circ} \mathrm{C}$ & $53 \%$ & $24,1^{\circ} \mathrm{C}$ & $49 \%$ \\
\hline $23,9{ }^{\circ} \mathrm{C}$ & $55 \%$ & $24{ }^{\circ} \mathrm{C}$ & $50 \%$ \\
\hline
\end{tabular}

According to the table above it can be seen that the DHT 11 sens or tested in the server room and outside the server room is not much different from the results with a Digital Thermometer indicating that the DHT 11 sensor is working properly.

\subsubsection{LCD Display Testing}

On the LCD that the temperature and humidity values are by the DHT11 sensor, this indicates that the sensor and LCD screen are operating smoothly. If the normal temperature is between $\pm 18^{\circ}-27^{\circ} \mathrm{C}$, the status will be written: normal. If the temperature is above the normal threshold, the temperature is above $\pm 27^{\circ} \mathrm{C}$, then the display on the LCD screen says status: periksa

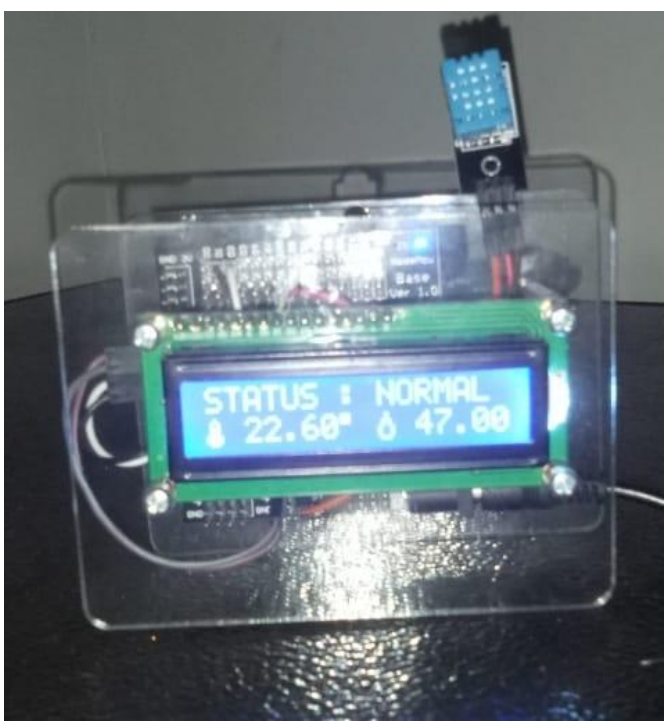

Figure 8. Status: Normal 


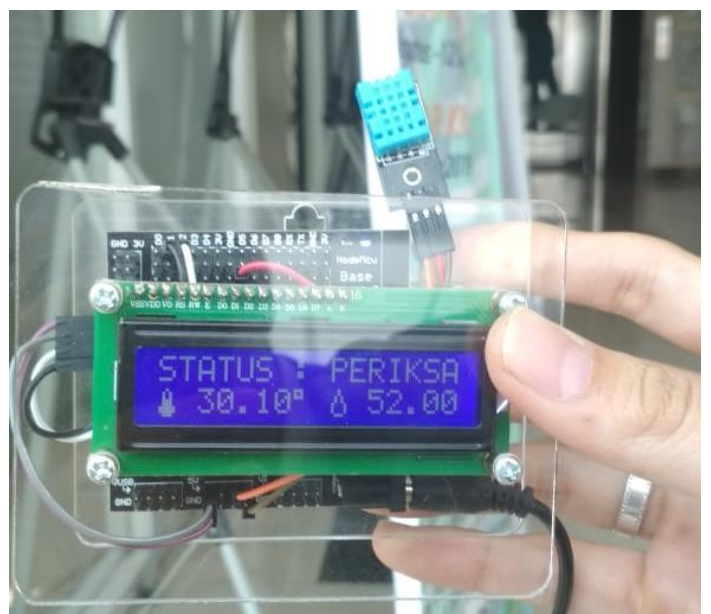

Figure 9. Status: Periks a

3.2.2. Interface Website Monitoring Result

Next is the appearance of a website for monitoring temperature and humidity that is directly connected to the NodeMCU microcontroller.

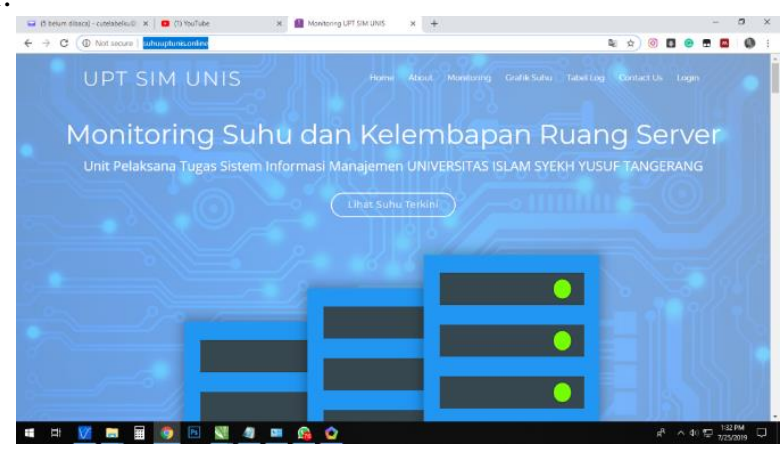

Figure 4. Homepage

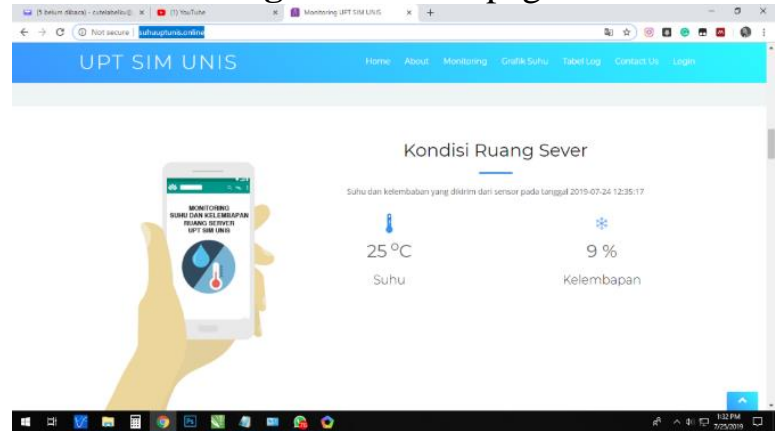

Figure 5. Room Server Condition

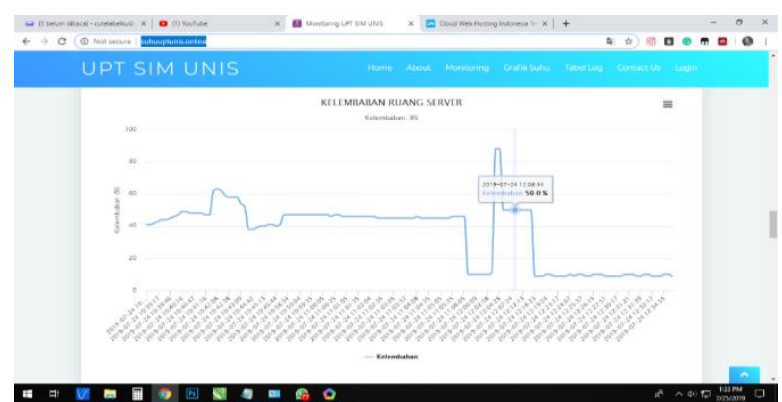

Figure 6. Humidity Graphic 


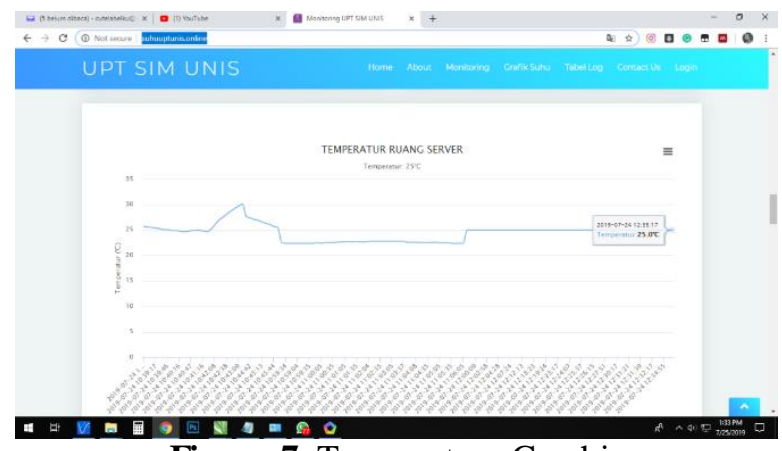

Figure 7. Temperature Graphic

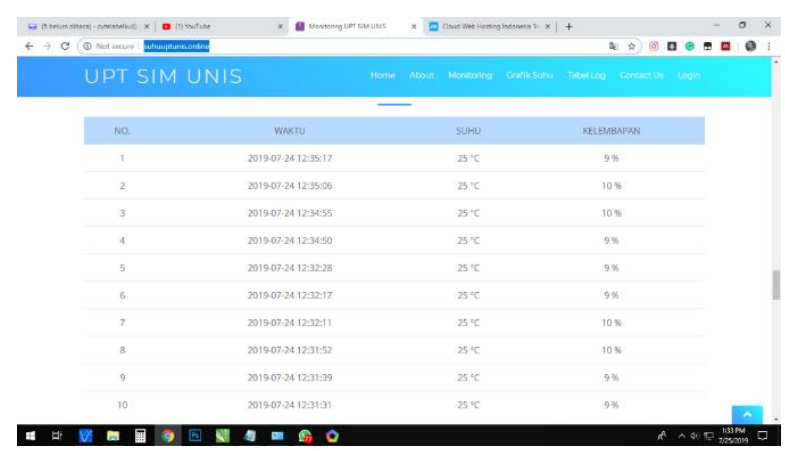

Figure 8. Table Log

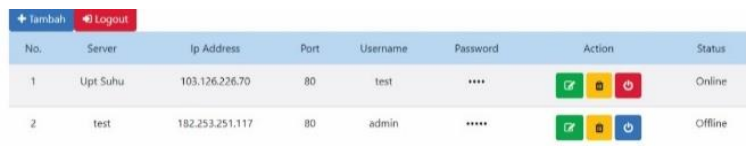

Figure 9. Server Status

3.3. Temperature Change Notification Testing

with severaldesigns that have been engineered, we have succeeded in making a system with several face to face as below:

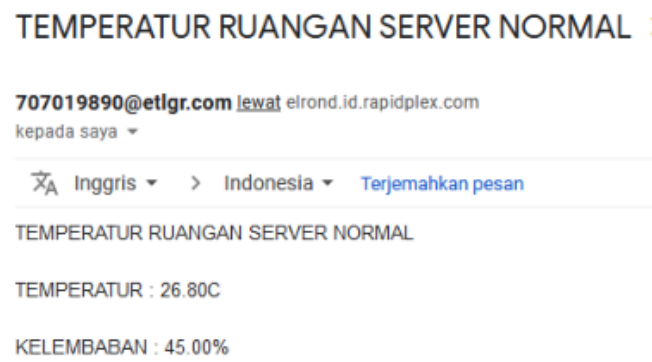

Figure 10. Email Notification Normal 


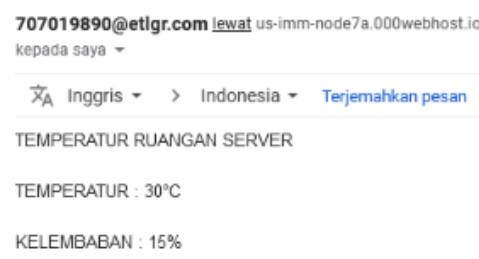

Figure 11. Email Notification Abnormal

11:03
$\leftarrow \quad S \quad \begin{aligned} & \text { suhuuptunis } \\ & \text { bot }\end{aligned}$
KELEMBABAN : $45.00 \%$
TEMPERATUR RUANGAN SERVER
NORMAL
TEMPERATUR : $22.80^{\circ} \mathrm{C}$
KELEMBABAN : $45.00 \%$

Figure 12. Telegram Notification

TEMPERATUR RUANGAN SERVER

TIDAK NORMAL

TEMPERATUR : $32^{\circ} \mathrm{C}$

KELEMBABAN : $15 \%$

Figure 13. Telegram Notification Abnormal

\section{Conclusion}

a. This systemhas been made that can monitor temperature and humidity periodically and help the server room admin in the UNIS so that they can adjust the temperature and humidity level of the server computer, and can see the status of the server is online or offline in the website that was created.

b. The system that has been made has been running well according to what was planned.

c. If there is a change in temperature, the system will notify via email and telegram that the server room needs to be checked.

\section{Suggestion}

a. Further research can be developed further, such as by restarting the server computer and other methods that can support the performance of IoT-based temperature and humidity monitoring.

b. This tool should require Wi-FiManager to be able to change the Wi-Fipass word via the website so that if the device is moved in a different place with SSID and a different password for the device connection, there is no need to reprogram and recompile.

c. If neces sary, this tool can be developed by using a battery as a power source, so that the tool can be placed anywhere without the need for a limited length cable adapter.

\section{References}

[1] S. F. Hassan, M. Ali, U. Perwez, and A. Sajid, "Free Cooling Investigation of RCMS Data Center," Energy Procedia, vol. 75, pp. 1249-1254, 2015.

[2] D. Purnomo, "Model Prototyping Pada Pengembangan Sistem Informasi,” J. Inform. Merdeka Pasuruan, vol. 2, no. 2, pp. 54-61, 2017.

[3] guruips.com, "Pengertian Suhu/Temperatur, Kelembapan Udara, Tekanan Udara, Angin, Curah Hujan, dan Awan," 2017. [Online]. Available: http://www.guruips.com/2017/09/pengertian-suhutemperatur-kelembapan.html. [Accessed: 15Feb-2019]. 
[4] P. Periyaldi, A. Bramanto, and A. Wajiansyah, "Implementasi Sistem Monitoring Suhu Ruang Server Satnetcom Berbasis Internet Of Things (Iot) Menggunakan Protokol Komunikasi Message Queue Telemetry Transport (Mqtt), JTT (Jurnal Teknol. Terpadu), vol. 6, no. 1, p. 23, 2018.

[5] A. Junaidi, "Internet of Things, Sejarah, Teknologi Dan Penerapannya: Review Internet of Things , Sejarah , Teknologi Dan Penerapannya : Review," Jitter, vol. I, no. AUGUST 2015, pp. 62-66, 2016.

[6] embeddednesia, "Mengenal NodeMCU: Pertemuan Pertama - embeddednesia.com," 2017. [Online]. Available: https://embeddednesia.com/v1/tut orial-nodemcu-pertemuan-pertama/. [Accessed: 13-Feb-2019].

[7] A. H. Saptadi and J. Arifin, "Sistem Pemantau Suhu dan Kelembaban Ruangan Dengan Notifikasi Via Email," Pros. Semin. Nas. Multi Disiplin Ilmu Call Pap. Unisbank, no. 128, pp. 978-979, 2016. 